\title{
POLLINIC PREPARATION FOR MORPHO-PALYNOLOGICAL STUDIES OF Passiflora L. SUBG. Passiflora L. (PASSIFLORACEAE)
}

\author{
PREPARAÇÕES POLÍNICAS PARA O ESTUDO DA MORFOLOGIA DO PÓLEN EM \\ Passiflora L. SUBG. Passiflora L. (PASSIFLORACEAE)
}

\author{
Sérgio Alessandro Machado SOUZA ${ }^{1}$, Kellen Coutinho MARTINS ${ }^{2}$, \\ Telma Nair Santana PEREIRA ${ }^{3}$ \\ 1. Professor, Doutor, Universidade do Estado de Mato Grosso - UNEMAT. Alta Floresta - MT, Brasil; \\ 2. Professora, Doutora, Universidade do Estado de Mato Grosso - UNEMAT. Alta Floresta - MT, Brasil; \\ 3. Professora, Doutora, Universidade Estadual do Norte Fluminense Darcy Ribeiro - UENF. Campos dos Goytacazes - RJ, Brasil. \\ telmasp@uenf.br
}

\begin{abstract}
The purpose of this study was to develop a pollen preparation methodology with a high proportion of intact pollen of species for the genus Passiflora subg. Passiflora. Thus, flower buds were collected near anthesis, from the species: $P$. alata, $P$. edulis, $P$. foetida, $P$. giberti, and $P$. setacea, fixed in ethanol-acetic acid mixture (3:1) and treated in 10\%-20\% aqueous sodium hydroxide, or acetolyzed. The pollen treated with $10 \%$ sodium hydroxide resulted in an average of $96 \%$ intact pollen grains in all species, however, after acetolysis an average percentage of $98 \%$ broken pollen was observed. Data obtained in pollen measurements did not change with the new methodology. It is therefore evident that the proposed methodology for pollen preparation based on sodium hydroxide was effective, as it allowed the visualization of a significant amount of intact pollen, thus promoting morpho-palynological studies of these species.
\end{abstract}

KEYWORDS: Pollen morphology. Pollen. Sodium hydroxide. Acetolysis.

\section{INTRODUCTION}

The genus Passiflora L. (Passifloraceae) is divided into four subgenera (Passiflora, Decaloba, Astrophea and Deidamoides). The most representative among them is Passiflora L. (FEUILETT AND MACDOUGAL, 2007), with approximately 140 described species in Brazil alone (CERVI, 2006; BERNACI et al., 2008). Aside from the large number of species, the variability in both vegetative and reproductive structures of the genus is impressive. A classification key, based on a larger number of descriptors associated with molecular studies (HANSEN et al., 2006), could eliminate errors in the systematic classification of this group.

Dettke and Santos (2009) stated that the family Passifloraceae is particularly interesting from the palynological point of view, due to the great variation in size and shape of the pollen grains. On the other hand, little is known about the pollen morphology, which could be important in the characterization of the genus Passiflora, using traits that have taxonomic value and could be useful to understand the systematics of the genus (MILVARD-DE-AZEVEDO et al., 2004) an efficient method of pollen preparation for such palynological studies would contribute to this purpose.

A number of methods for morpho- palynological studies have been cited in the literature, for example, acetolysis developed by Erdtman (1960), lactic acetolysis by Raynal and Raynal (1971) and the method of Wodehouse (1935). But in palynological studies with species of the subgenus Passiflora, the results of the above methodologies in pollen preparations for bright-field microscopy are unsatisfactory, as reported by Araújo and Santos (2004); Dettke and Santos (2009) and Evaldt et al., (2011). The development of a methodology for a good pollen preparation could circumvent this problem, underlying palynological studies of the species of this group.

Thus, the purpose of this study was to develop a methodology of pollen preparation producing a high proportion of intact pollen grains for morpho-palynological studies of species of the subgenus Passiflora under bright-field microscopy.

\section{MATERIAL AND METHODS}

The pollen material was obtained from flower buds near anthesis, of the species: Passiflora alata Curtis, Passiflora edulis Sims, Passiflora foetida L., Passiflora giberti N. E. Brow and Passiflora setacea DC. To obtain pollen material from each species, buds were collected and fixed in 3:1 ethanol-acetic acid and refrigerated $\left(4^{\circ} \mathrm{C}\right)$ for at least 24 hours. Subsequently, two anthers per bud were removed, cross-sectioned, transferred to 1000 
$\mu \mathrm{L}$ microtubes containing $500 \mu \mathrm{L}$ of acetic acid and left to stand for $15 \mathrm{~min}$. After the pollen material was exposed, the anthers were removed and the tubes centrifuged at $3000 \mathrm{rpm}$ (rotations per minute) for $5 \mathrm{~min}$ and then the supernatant was discarded.

After separating the pollen material according to the above method for each species, two techniques were used independently for the preparation for bright field microscopy analysis: a) acetolysis of pollen grains as proposed by Erdtman $(1960)$, b) sodium hydroxide $(\mathrm{NaOH})$ in aqueous solution at $10 \%(\mathrm{v} / \mathrm{v})$ and $20 \%(\mathrm{v} / \mathrm{v})$, where $500 \mathrm{uL}$ of 10 or $20 \%$ of the solution was filled into a microtube containing the pollen material, and incubated for $15 \mathrm{~min}$ at room temperature, then slides were prepared in glycerol gelatin and the material was analyzed.

Per slide, 250 pollen grains were analyzed, a total of eight slides for each of the five species, i.e. a total of 10,000 pollen grains, distinguishing the intact from the damaged (broken or partially broken) grains. The data were subjected to descriptive statistics, using measures of central tendency and data variability, and the confidence interval for the proportion was estimated at a significance level of $0.05 \%$, using the program GENES (CRUZ, 2006). Measurements in polar view of the polar pollen diameter were also carried out for all species.

\section{RESULTS AND DISCUSSION}

Pollen preparation by the acetolysis method resulted in partially or completely broken pollen grains, however, preparing the pollen on the basis of $\mathrm{NaOH}$ allowed a clear visualization of the morphology of the pollen of all species of this study (Figure 1). In some studies (ARAÚJO and SANTOS, 2004; DETTKE et al., 2009 and EVALDT et al., 2011), acetolyzed pollen of representatives of the subgenus Passiflora under bright-field microscopy appeared with partially or completely broken grains, hampering some estimations, e.g., of the polar and the equatorial diameter.
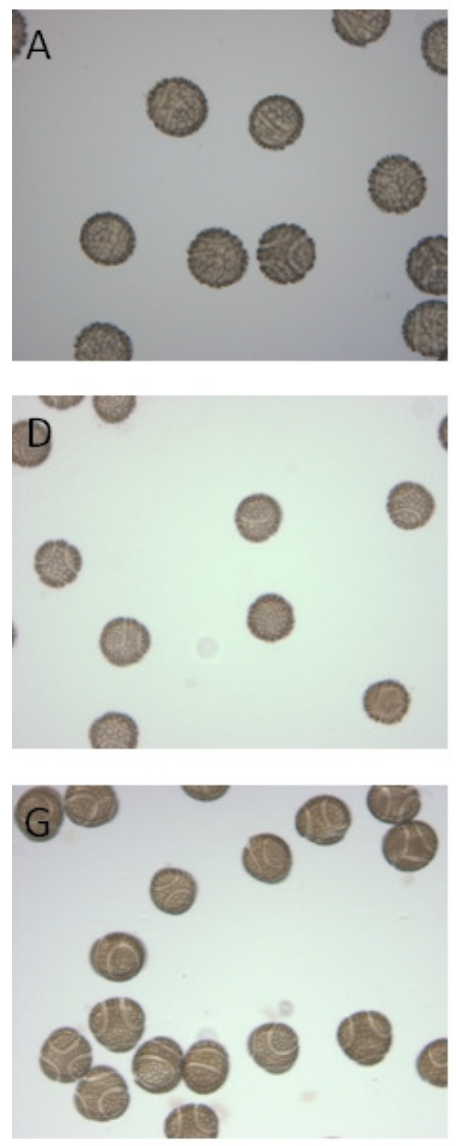
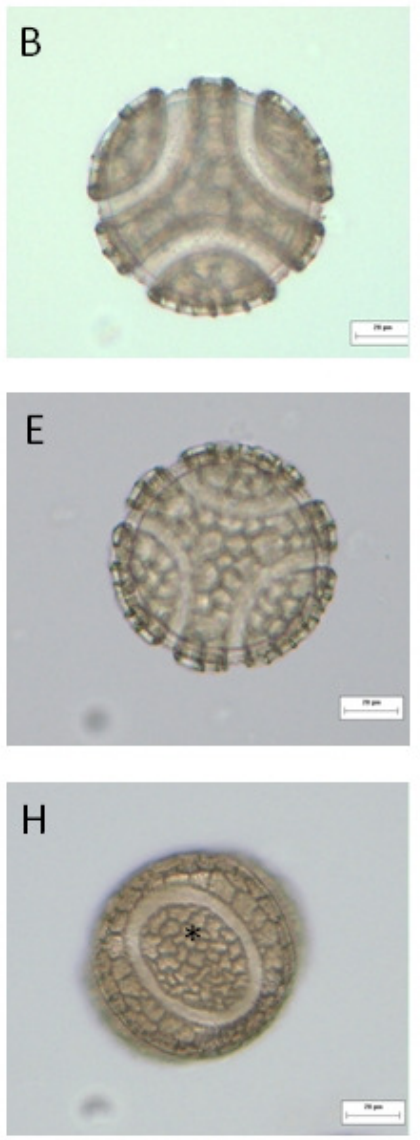
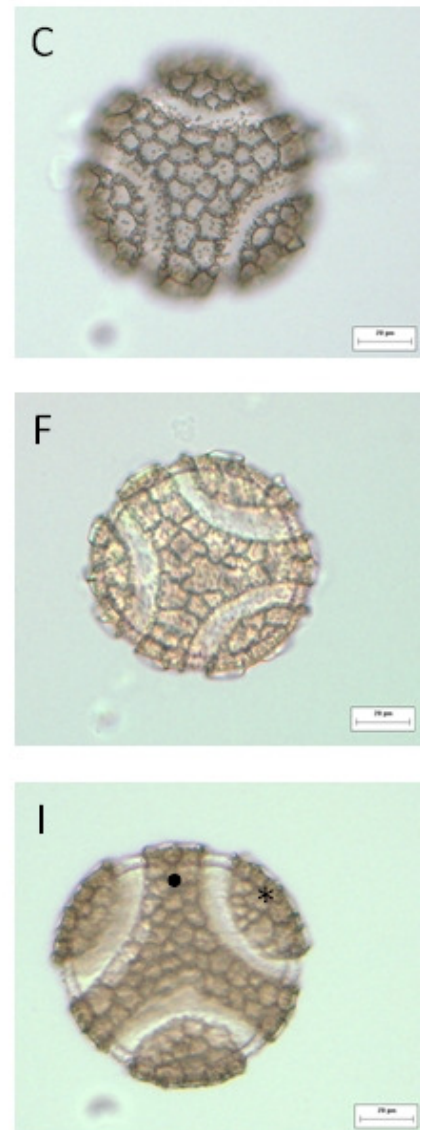

Figure 1. Photomicrographs of $\mathrm{NaOH}$-treated pollen grains of species of the subgenus Passiflora. (ADG) set of intact pollen, respectively, of $P$. edulis, $P$. alata e P. setacea; (B) P. edulis, (C) P. foetida, (E) $P$. alata, (F) P. giberti and (I) P. setacea in polar view; (H) P. setacea in equatorial view; (*) pseudoperculum and $(\bullet)$ pontoperculum. Bar $20 \mu \mathrm{m}$. 
Well-prepared pollen grains, aside from maintaining the pollen integrity, should show the outer pollen membrane, making a clear distinction between the nexine and sexine possible (SALGADO-LABOURIAU, 1973; MARTINS, 2010). The data from this study corroborated statements of the above authors, since the use of aqueous $\mathrm{NaOH}$ allowed a good visualization of these structures (Figure 1). In addition, a high percentage of intact pollen was observed resulting from preparation with $10 \% \mathrm{NaOH}: P$. alata $(97 \%)$, P. edulis (95\%), P. foetida (97\%), P. giberti (96\%), and $P$. setacea $(98 \%)$, while the in preparation with 20\% NaOH: P. alata (88\%), P. edulis (90\%), P. foetida (91\%), P. giberti (88\%), and P. setacea (93\%) (Table 1).

Table 1. Confidence interval (CI), at a significance level of 0.05 for the proportion (p) of intact and broken pollen of the species $P$. alata, $P$. edulis, $P$. foetida, $P$. giberti, and $P$. setacea, after pollen preparation by different methods.

\begin{tabular}{|c|c|c|c|c|c|}
\hline \multirow[b]{2}{*}{ Species } & \multirow{3}{*}{ Methodology } & \multicolumn{4}{|c|}{ Proportion } \\
\hline & & Intact pollen & & Brok & \\
\hline \multirow{4}{*}{ P. alata } & & $p$ & CI $(95 \%)$ & $p$ & CI $(95 \%)$ \\
\hline & acetolysis & 0.02 & $0.01-0.03$ & 0.98 & $0.97-0.99$ \\
\hline & sodium hydroxide (10\%) & 0.97 & $0.95-0.99$ & 0.03 & $0.01-0.05$ \\
\hline & sodium hydroxide $(20 \%)$ & 0.88 & $0.87-0.91$ & 0.12 & $0.09-0.13$ \\
\hline \multirow{3}{*}{ P. edulis } & acetolysis & 0.01 & $0.01-0.03$ & 0.99 & $0.97-0.99$ \\
\hline & sodium hydroxide $(10 \%)$ & 0.95 & $0.95-0.98$ & 0.05 & $0.02-0.05$ \\
\hline & sodium hydroxide $(20 \%)$ & 0.90 & $0.86-0.90$ & 0.10 & $0.10-0.14$ \\
\hline \multirow{3}{*}{ P. foetida } & acetolysis & 0.02 & $0.01-0.03$ & 0.98 & $0.97-0.99$ \\
\hline & sodium hydroxide $(10 \%)$ & 0.97 & $0.95-0.99$ & 0.03 & $0.01-0.05$ \\
\hline & sodium hydroxide $(20 \%)$ & 0.91 & $0.87-0.93$ & 0.11 & $0.07-0.13$ \\
\hline \multirow{3}{*}{ P. giberti } & acetolysis & 0.03 & $0.01-0.04$ & 0.97 & $0.96-0.99$ \\
\hline & sodium hydroxide $(10 \%)$ & 0.96 & $0.95-0.99$ & 0.03 & $0.01-0.05$ \\
\hline & sodium hydroxide $(20 \%)$ & 0.88 & $0.87-0.91$ & 0.12 & $0.09-0.13$ \\
\hline \multirow{3}{*}{ P. setacea } & acetolysis & 0.02 & $0.01-0.03$ & 0.98 & $0.97-0.99$ \\
\hline & sodium hydroxide $(10 \%)$ & 0.98 & $0.94-0.99$ & 0.02 & $0.01-0.06$ \\
\hline & sodium hydroxide $(20 \%)$ & 0.93 & $0.90-0.95$ & 0.07 & $0.05-0.10$ \\
\hline
\end{tabular}

The measurements in equatorial view showed the following average values of polar diameter of the species, $P$. edulis $(69.2 \mu \mathrm{m}), P$. alata $(73.3 \mu \mathrm{m})$, P. foetida $(79.6 \mu \mathrm{m})$, P. giberti $(78.5$ $\mu \mathrm{m})$ and $P$. setacea $(79.4 \mu \mathrm{m})$ and equatorial diameter of $70.2,72.5,75.1,80.3$ e $79.0 \mu \mathrm{m}$, respectively, to above species (Table 2). Similar values were found by Evaldt et al. (2011) for $P$. alata, $P$. edulis and $P$. foetida, using acetolysis method, this fact indicates that the proposed methodology does not underestimate the pollen measurements of the species studied.

Table 2. Morphometric characteristics of pollen grains of species for the genus Passiflora subg. Passiflora.

\begin{tabular}{|c|c|c|c|c|c|c|c|c|c|c|}
\hline Species & $\begin{array}{l}\text { Polar } \\
\text { diameter } \\
\text { Range }\end{array}$ & $\mathrm{x} \pm \mathrm{s}_{\mathrm{x}}$ & $\mathrm{s}$ & CI 95\% & $\begin{array}{l}\text { CV } \\
(\%)\end{array}$ & $\begin{array}{l}\text { Equatorial } \\
\text { diameter } \\
\text { Range }\end{array}$ & $x \pm s_{x}$ & $\mathrm{~s}$ & CI 95\% & $\begin{array}{l}\text { CV } \\
(\%)\end{array}$ \\
\hline P. edulis & $65.3-75.4$ & $69.2 \pm 1.5$ & 2.9 & $68.3-71.2$ & 4.1 & $64.7-76.1$ & $70.2 \pm 1.4$ & 2.5 & $69.0-72.3$ & 3.5 \\
\hline P. alata & $62.1-84.7$ & $73.3 \pm 1.8$ & 1.3 & $70.5-74.0$ & 3.9 & $61.8-83.9$ & $72.5 \pm 3.5$ & 3.7 & $70.1-74.8$ & 5.1 \\
\hline P. foetida & $65.6-94.5$ & $76.9 \pm 2.4$ & 2.0 & $75.2-78.5$ & 2.6 & $66.1-95.3$ & $75.1 \pm 1.9$ & 3.0 & $74.0-77.4$ & 3.9 \\
\hline P. setacea & $70.1-83.2$ & $79.4 \pm 1.3$ & 1.7 & $78.8-80.7$ & 2.1 & $69.8-84.7$ & $80.3 \pm 3.0$ & 2.9 & $78.5-81.6$ & 3.6 \\
\hline P. giberti & $64.8-80.1$ & $78.5 \pm 2.0$ & 3.2 & $76.5-80.9$ & 4.0 & $62.2-82.3$ & $79.0 \pm 2.7$ & 3.4 & $78.4-81.0$ & 4.3 \\
\hline
\end{tabular}


It is therefore evident that the proposed methodology resulted in a significant amount of intact pollen grains and enabled a clear visualization of the pollen morphology, thus representing a viable alternative for palynological descriptions of the studied in Passiflora species.

\section{ACKNOWLEDGEMENTS}

The authors wish to thank the Research Foundation of the State of Rio de Janeiro (FAPERJ) for a Ph.D. scholarship to the first author.

RESUMO: Este estudo teve como objetivo elaborar uma metodologia, para obter preparos polínicos com alta frequência de polens íntegros de espécies representantes do gênero Passiflora subg. Passiflora. Dessa forma, botões florais foram coletados, próximo à antese, das seguintes espécies: $P$. alata, $P$. edulis, $P$. foetida, $P$. giberti e $P$. setacea, fixado em solução etanol-ácido acético (3:1) e tratado em solução aquosa de hidróxido de sódio (10 e 20\%) ou acetolisados, independentemente. Os preparos palinológicos, quando tratados com hidróxido de sódio a 10\%, evidenciaram, em todas as espécies, média de $96 \%$ de polens íntegros, em contrapartida, quando acetolisados foi observada uma percentagem média de $98 \%$ de polens rompidos. Os dados referentes a mensurações polínicas não sofreram alterações com a nova metodologia. Evidencia-se, dessa forma, que a metodologia proposta, para preparações polínicas à base de hidróxido de sódio, foi eficiente, pois promoveu a visualização de uma quantidade significativa de polens íntegros, favorecendo assim o estudo da morfologia polínica nessas espécies.

PALAVRAS CHAVES: Morfologia polínica. Pólen. Hidróxido de sódio. Acetólise.

\section{REFERENCES}

ARAÚJO, R. C. M.; SANTOS, F. A. R. Palinologia de Espécies do Gênero Passiflora L. (Passifloraceae) da Chapada Diamantina, Bahia, Brasil. Sitientibus: Série Ciências Biológicas, Feira de Santana, v. 4, n. 1/2, p. 37 42. 2004.

BERNACCI, L. C.; SOARES-SCOTT, M. D.; JUNQUEIRA, M. T. V.; PASSOS, I. R. S.; MELETTI, L. M. M. Passiflora edulis Sims: the correct taxonomic way to cite the yellow passion fruit (and of others colors), Revista Brasileira de Fruticultura, Jaboticabal, v. 30, n. 2, p. 566-576, 2008.

CERVI, A. C. O gênero Passiflora (Passifloraceae) no Brasil, espécies descritas após o ano de 1950. Adumbrationes ad Summae Editionem, p. 1-5. 2006.

CRUZ, C. D. Programa genes: estatística experimental e matrizes. Viçosa: UFV, 2006. 346p.

DETTKE, G. A.; SANTOS, R. P. Tipos de aberturas dos grãos de pólen de espécies de Passiflora L. (Passifloraceae), Acta Botânica Brasilica, São Paulo, v. 23, n. 4, p. 1119-1129, 2009. http://dx.doi.org/10.1590/S0102-33062009000400021

ERDTMAN, G. The acetolysis method. A revised description. Svensk Botanisk Tidskrift, v. 54, p. 561-564, 1960.

EVALDT, A. C. P.; BAUERMANN, S. G.; CANCELLI, R. R; ACIOLI, M.; NEVES, P. C. P. Morfologia polínica de Passifloraceae Juss ex Kunth. no Rio Grande do Sul, Brasil. Revista Brasileira de Biocências, Porto Alegre, v. 9, n.s1, p. 75-87, 2011.

FEUILLET, C.; MACDOUGAL, J. M. Passifloraceae. In: Kubitzki, K. The families and genera of vascular plants. Berlin: Springer, 2007, p. 270-281. http://dx.doi.org/10.1007/978-3-540-32219-1_35

HANSEN A. K.; GILBERT, L. E.; SIMPSON, B. B; DOWNIE, S. R.; CERVI, A. C.; JANSEN, R. K. Phylogenetic relationships and chromosome number evolution in Passiflora. Systematic Botany, Laramie, v. 31, n. 1, 2006, p. 138-150. http://dx.doi.org/10.1600/036364406775971769 
MARTINS, K.C. Morfologia polínica: aplicações, estudos e metodologias, Rio de Janeiro: CBJE, 2010, 75p.

MILWARD-DE-AZEVEDO, M. A.; SOUZA, F. C.; BAUMGRATZ, J. F. A.; GONÇALVES-ESTEVES, V. Palinotaxonomia das espécies de Passiflora L. subg. Decaloba (DC.) Rchb. (Passifloraceae) no Sudeste do Brasil. Revista Brasileira de Botânica, São Paulo, v. 27, n. 4, p. 655-665, 2004.

http://dx.doi.org/10.1590/s0100-84042004000400006

RAYNAL, A.; RAYNAL, J. Une technique de préparation des grains de pollen fragiles. Adansonia, v. 11, p. 77-79, 1971.

SALGADO-LABOURIAU, M. L. Contribuição à palinologia dos cerrados. Rio de Janeiro: Academia Brasileira de Ciências, 1973, 291p. 